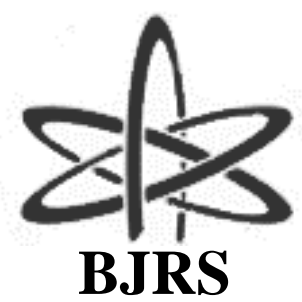

BRAZILIAN JOURNAL

$\mathrm{OF}$

RADIATION SCIENCES

06-02 (2018) 01-18

\title{
Dirty bomb radiological simulations: two explosion scenarios using the Rio 2016 Olympic games Athletes' Village as a model
}

\author{
J. F. Pereira ${ }^{\mathrm{a}}$; J. U. Delgado \\ ${ }^{a}$ Brazilian Nuclear Energy Commission, Institute for Radiation Protection and Dosimetry, Emergency Group, \\ Rio de Janeiro, Rio de Janeiro, Brazil \\ jfrancis@ird.gov.br \\ ${ }^{\mathrm{b}}$ Brazilian Nuclear Energy Commission, Institute for Radiation Protection and Dosimetry LNMRI,
}

Rio de Janeiro, Rio de Janeiro, Brazil

\begin{abstract}
A historic moment in terrorist bombing in the world was the explosion of the twin towers in the USA, starting a new series of attacks. The bombing brought up many concerns for security authorities all over the world. However, no study about this kind of terrorism involving Olympic venues or big events has ever been published considering dirty bombs with radiological material. This study aims to present, using US NARAC HotSpot Code, a procedure that combines two realistic potential scenarios in the event of a terrorist attack involving the explosion of a Radiological Dispersion Device (dirty bomb) that contains two radionuclides, ${ }^{137} \mathrm{Cs}$ and ${ }^{241} \mathrm{Am}$, in the Olympic Village. The results are shown in terms of effective dose (E) and deposition of radioactive material in the soil, which will provide security authorities with information for immediate radiological emergency response actions in order to protect the public and emergency first responders. This study considers a scenario with a dirty bomb explosion during the Rio 2016 Olympic Games that hosted 10,500 athletes from 205 different countries in the Olympic Village. For the calculations of this study the HotSpot code was applied, allowing for emergency response teams to predict the environmental impact depending on the radionuclide used, of the Pasquill stability class, according to the different quantities of explosive, the height of the explosion and the distance in meters from the point of the explosion. It was observed that ${ }^{241} \mathrm{Am}$ has a higher dose level than ${ }^{137} \mathrm{Cs}$, while the ground deposition of ${ }^{137} \mathrm{Cs}$ was higher.
\end{abstract}

Keywords: dirty bomb, US NARAC HotSpot, big event, radiological emergency, terrorist attack. 


\section{INTRODUCTION}

Since terrorists bombed the twin towers on September 11, 2001, other terrorist attacks continue to take place. Authorities that respond to radiological emergencies are concerned that a radiological dispersion device (RDD) [1] or dirty bomb explosion could be used by a person or group and cause psychological and material damage to the population, with the dispersion of radioactive material in the environment. This would cause great economic losses for countries, due to the enormous response action costs of decontamination and resettlement of the population.

Dirty bombs were already a problem long before September 11, 2001. The Iraqi government tested a one-ton radiological bomb in 1987 and observed that a dirty bomb with radioactive material is not effective as a weapon of mass destruction and that its main value is as a psychological weapon [2]. The Chechen rebels buried a dirty bomb in a park in Moscow in 1995, issuing a detonation threat if their demands were not met [2]. Although Brazil does not currently have this problem, there is great concern of it being victim of a radiological dirty bomb terrorist attack.

The RDD or dirty bomb is an artifact that contains radioactive material attached to the conventional explosive, used to explode and deliberately disperse radioactive material and create a terror situation, causing damage to the population and environment. A terrorist attack can bring about high expenditure on cleaning and decontamination, and have secondary impacts on water supply reservoirs, with two major long-term concerns regarding human health and economic impacts, and major financial losses for protecting buildings and human lives [3].

The radionuclides ${ }^{238} \mathrm{Pu},{ }^{210} \mathrm{Po},{ }^{241} \mathrm{Am},{ }^{90} \mathrm{Sr},{ }^{137} \mathrm{Cs},{ }^{252} \mathrm{Cf},{ }^{60} \mathrm{Co},{ }^{226} \mathrm{Ra}$ and ${ }^{192} \mathrm{Ir}$ can be used in an RDD, and are selected based on portability, relatively low security (readily obtainable), relatively high specific activities, and physical and chemical forms [4]. An RDD explosion causes heat and generates enough energy to propel and immediately spread radioactive material over a significant area, with a reach of a few meters up to hundreds of meters.

The International Atomic Energy Agency (IAEA) and the US government have a strict control system for radioactive material. There is a significant amount of radioactive material stored in medical centers that is used to diagnose and treat diseases in research laboratories. It is also present in food 
processing and irradiation installations to eliminate fungi, bacteria and microbes in radio-thermal generators, as well as nuclear instrumentation used for oil well prospecting.

Then, considering that current terrorist attacks are increasingly sophisticated, with the use of explosive devices, using an RDD as a dirty bomb can no longer be neglected. This is because: (a) it could occur anywhere and at any time during a big event, shocking people, families, society as a whole, and bringing major concerns, in particular, to members of the response teams; (b) the first actions of an emergency team are still based on general response procedures, which, in turn, are supported by information obtained in guides and manuals adapted from experiments acquired in radiological accidents and/or in nuclear installations, for example Goiânia and Chernobyl; and (c) due to the lack of a minimum foreknowledge about the explosion of RDDs in big public events, the first actions related to an attack could be conducted in an improvised way, based only on empirical data and on members' personal experiences [5].

Brazilian radiological emergency response teams have already gained extensive experience at major public events. The competence has been developed whilst ensuring radiological security at big events, such as the Pan American Games [6]; Military Games; Rio+ 20 Meeting; Confederations Cup, FIFA World Cup and Olympic Games 2016 via scanning areas, public access control and monitoring of all activities and Venues; Pope's Pilgrims; and State Chief Meetings [7]. The Rio 2016 Olympic Games Athletes' Village received 10,500 athletes and delegates, hosted in a total of 3,604 apartments in 31 buildings during the Rio 2016 Olympic Games.

An efficient simulation tool is the US NARAC HotSpot code, which is an atmospherics dispersion model used by the National Center for Atmospheric Supervision of the United States of America and radiological security agencies from other countries to predict air concentrations and soil deposition of radioactive material due to a dirty bomb detonation $[8 ; 9 ; 6]$.

The objective of this study is to present a procedure calculation that combines two realistic potential scenario calculations in the case of a terrorist attack via a dirty bomb explosion in the Olympic Village, with the use of two representative radionuclides, ${ }^{137} \mathrm{Cs}$ and ${ }^{241} \mathrm{Am}$, using the US NARAC HotSpot code. Additionally, the objective is to obtain results of the (E) as well as information about the amount of radioactive material deposited in the soil, for radiological emergency first response planning. Such study could also be applied in other important cities in the world that will host big events. 


\section{MATERIALS AND METHODS}

\subsection{Using the Gaussian model in the HotSpot Code to determine radioactive material concentration in the air}

The Gaussian model has been widely used and verified in the scientific community and is still the basic workhorse for initial atmospheric dispersion calculations. The Gaussian model generally produces results that agree well with experimental data and, as a result, has found its way into most governmental guidebooks, and is also used and accepted by the Environmental Protection Agency [10]. The origin of the Gaussian model is found in work by Sutton, Pasquill and Gifford $[11 ; 12 ; 13$; 14]. Later on, Briggs (1973) combined the Pasquill curves with curves derived from data observed at Brookhaven National Laboratory and the Tennessee Valley Authority, the latter including observations out to a downwind distance of $10 \mathrm{~km}$. Briggs incorporated theoretical concepts regarding asymptotic limits of the formulas to produce a widely used set of equations for $\mathrm{y}$ and $\mathrm{z}$ $[15 ; 16 ; 17]$.

The $\mathrm{x}$-axis is the downwind axis, extending horizontally with the ground in the wind direction. The $y$-axis is the crosswind axis, perpendicular to the downwind axis, also extending horizontally. The z-axis extends vertically from the ground. A plume travels along, or parallel to, the downwind axis, and reflects off the ground surface when the plume touches down. Figure 1 shows the Gaussian model diagram used in the HotSpot code to determine radioactive material concentration in the air. 
Figure 1: The Gaussian model diagram.

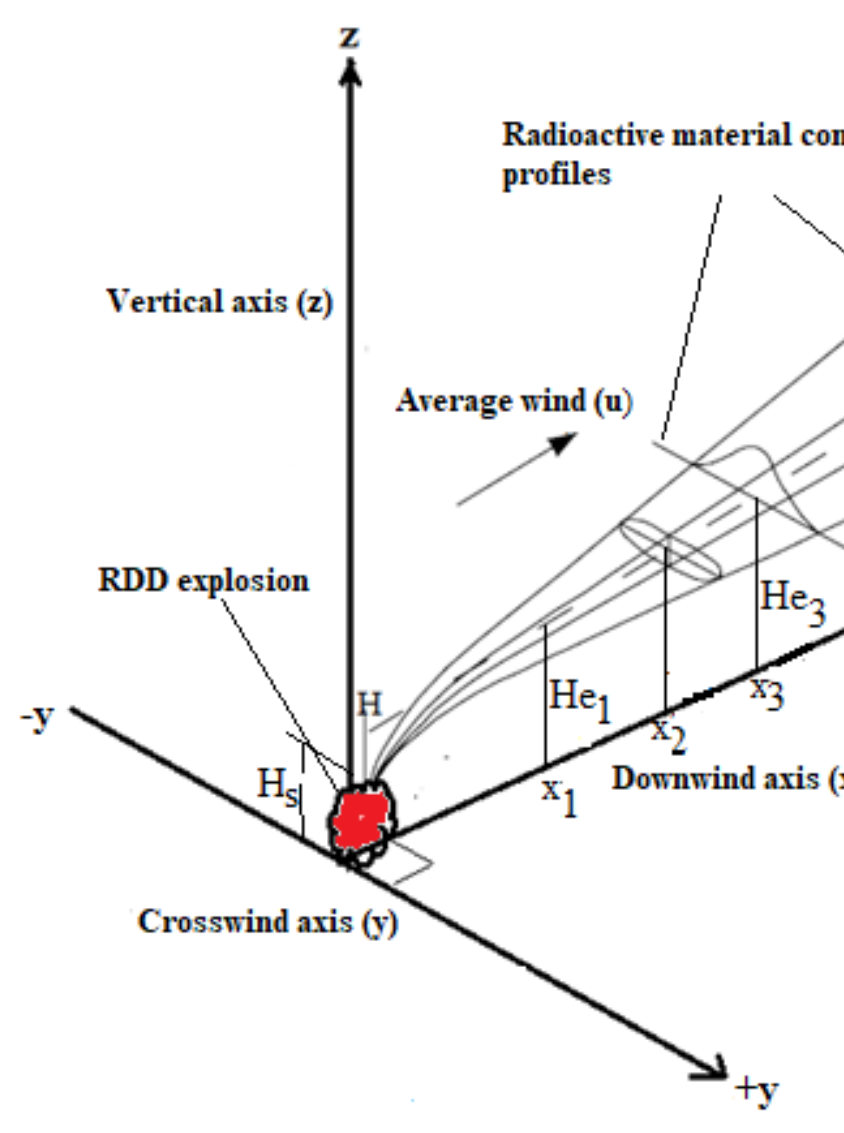

Time average

Plume centerline

Radioactive material concentration profiles

r 
$\mathrm{C}$ is the time-integrated atmospheric concentration of the radionuclide in air (Bq.s $/ \mathrm{m}^{3}$ )

$\mathrm{Q}$ is the source term $(\mathrm{Bq})$

$\mathrm{H}$ is the explosion effective height $(\mathrm{m})$

$\lambda$ radioactive decay constant $\left(\mathrm{s}^{-1)}\right.$

$\mathrm{x}$ downwind distance $(\mathrm{m})$

$\mathrm{y}$ crosswind distance perpendicular to the wind $(\mathrm{m})$

$\mathrm{z}$ vertical distance $(\mathrm{m})$

$\sigma$ (y) standard deviation of the integrated concentration distribution in the crosswind direction (m)

$\sigma_{(\mathrm{z})}$ standard deviation of the integrated concentration distribution in the vertical direction (m)

$\mathrm{u}$ wind speed $(\mathrm{m} / \mathrm{s})$

The dose calculation performed by the HotSpot code assumes that the target individual remains at the same downwind location $(\mathrm{x}, \mathrm{y}, \mathrm{z})$ throughout the passage of the plume and that by default the release duration of radioactive material is 10 minutes. The improved formula by Briggs allows for calculations from a distance of $0.1 \mathrm{~km}$ to approximately $10 \mathrm{~km}$ and is extendible to 20 or $30 \mathrm{~km}$, although Briggs does not recommend this extension. However, for lack of any other validation scheme, these formulas are commonly used out to a distance of $100 \mathrm{~km}$.

\subsection{The US NARAC HotSpot code}

The US NARAC HotSpot code was selected in order to perform consequent assessments of potential dirty bomb scenarios using radiological material in urban areas. Its main advantages as a radiological emergency response code include some capabilities to model the dispersal of radioactive material due to an explosion, to display contamination levels in units that emergency responders are familiar with, and to provide a plot of the contaminated area and calculate the contamination level in that square area [8].

It is also helpful for preventative actions and implementing countermeasures of emergency preparedness and response systems. It would provide quantitative model outputs, which may guide the deployment of health physics survey teams and assist in making more specific emergency management decisions in the case of any radiological release. The results of the code are reliable for a distance near $10 \mathrm{~km}$, however beyond this distance the results need to be analyzed more carefully. 
HotSpot saves, in KML format, all the information used in the calculations for determining the effective dose and deposition, and then Google Earth uses the geographical coordinates defined by the user to plot the graphics of dose and deposition behaviors from the point of explosion in the predominant direction of the wind [18]. Google Earth does not change the altitudes to correct the plume dispersion. In fact, it uses all the predefined information stored in the KML file for the simulations, such as altitude, geographical coordinates, amount of explosive, prevailing wind direction, from the point of the explosion in order to plot the surface maps for $\mathrm{E}$ and deposition.

\subsection{Initial considerations and running simulations}

The Olympic Village of the Rio 2016 Olympic Games hosted 10,500 athletes from 205 different countries, bringing about many concerns for the security authorities during this big event. These concerns affect the population and authorities in a general manner nowadays, whilst major public events or sporting events are taking place. The proposed scenario foresees a terrorist attack in the Athletes' Village of the Rio 2016 Olympic Games, with the release of radioactive substances.

A terrorist attack scenario with the deployment of a dirty bomb destined for events of this magnitude has not been considered in literature until today, due to classified restrictions. In this study, we present realistic potential scenarios in the case of a terrorist attack in the Olympic Village, involving the explosion of a dirty bomb that uses two different radionuclides.

According to international organizations, in general, the nine radionuclides that could possibly be used in an RDD are: ${ }^{238} \mathrm{Pu},{ }^{210} \mathrm{Po},{ }^{241} \mathrm{Am},{ }^{90} \mathrm{Sr},{ }^{137} \mathrm{Cs},{ }^{252} \mathrm{Cf},{ }^{60} \mathrm{Co},{ }^{226} \mathrm{Ra}$ and ${ }^{192} \mathrm{Ir}$. The methodology adopted considered explosions of an RDD with ${ }^{137} \mathrm{Cs}$ and ${ }^{241} \mathrm{Am}$ in the Olympic Village, and in terms of effective dose (E) includes the internal and external contributions of the total absorbed dose as also the deposition of radioactive material in the soil, depending on the distance in meters from the point of the explosion. In general, these two radionuclides are representatives of the nine cited above because they have the same physical characteristics, such as type of radiation, half-life and energy of emission. They were also selected for the following reasons: ${ }^{137} \mathrm{Cs}$ is highly dispersive in the air, with $\beta$ and $\gamma$ exposition (for example, fission products, such as ${ }^{60} \mathrm{Co},{ }^{90} \mathrm{Sr}$ and ${ }^{152} \mathrm{Ir}$ ), while ${ }^{241} \mathrm{Am}$ causes $\alpha$ and $\gamma$ expositions such as the transuranic elements of high toxicity, i.e., ${ }^{239} \mathrm{Pu},{ }^{210} \mathrm{Po},{ }^{226} \mathrm{Ra},{ }^{252} \mathrm{Cf}$. 
The meteorological parameters as input computer code were $\mathbf{E}$ for the stability class, with wind direction set by wind rose, the Village set to 225.0 degrees with respect to True North, the value of wind speed assumed for the simulation as $1 \mathrm{~m} / \mathrm{s}$, and with 10,500 persons accommodated in the Village. The topography was determined by public satellite information. The radioactive sources were composed of ${ }^{241} \mathrm{Am}$ with $74 \mathrm{GBq}$ and ${ }^{137} \mathrm{Cs}$ with $48.1 \mathrm{TBq}$ activities. The explosives for the calculations contained $1.36 \mathrm{~kg}$ of trinitrotoluene (TNT) equivalent.

The International Commission for Radiological Protection [16] recommends exposure limits for gamma radiation, but the explosion of an RDD, obviously, may result in the exposure to the public and emergency workers of concentrations exceeding the expected limits. By multiplication of the time-integrated air concentration with an inhalation rate of $3.3 \times 10^{-4} \mathrm{~m}^{3} \cdot \mathrm{s}^{-1}$ the total inhaled amount of contamination can be found. Table 1 shows the main radionuclide characteristics and Table 2 shows radionuclide properties, where power to contaminate relates to the area impacted by the dirty bomb.

The most likely sources used by terrorists are those that are easily stolen, such as density gauges, well logging sources, radiography sources, and medical sources. These have relatively low levels of security. The hypotheses is that a terrorist group acquires radioactive material from the illegal market, consisting of ${ }^{137} \mathrm{Cs}$ in Salt $(\mathrm{CsCl})$ chemical form from an old irradiator and ${ }^{241} \mathrm{Am}$ in Oxide Powder chemical from a well logging device [17]. The sources used for a dirty bomb would have high energy and a long decay constant, so that they could maximize the consequences on the public $[18 ; 4]$.

The radiological terror results in a widespread contamination that requires long-term decontamination. The ${ }^{137} \mathrm{Cs}$ and ${ }^{241} \mathrm{Am}$ were selected for the simulation for the reason that the ${ }^{137} \mathrm{Cs}$ is highly dispersible in the air in a powdered form and causes external exposure due to $\gamma$ and $\beta$ radiation hazard, whereas ${ }^{241} \mathrm{Am}$ causes the internal exposure of $\alpha$ and $\gamma$ radiation hazard. This material allows for the creation of a "dirty bomb", assembled to a plastic explosive (readily available) and with a remote trigger device. Likely explosives are Trinitrotoluene (TNT), Ammonium Nitrate/Fuel Oil (ANFO), and plastic explosives such as Semtex, C-3, C-4, etc. The bomb is secured inside the trunk of a car and the same is then placed in a short stay car park at the 
Athletes' Village, with 10,500 persons, and placed at a higher level than the parking level (about 1.5 meters).

Table 1: Main radionuclide characteristics used during simulations [19].

\begin{tabular}{cccccc}
\hline & Specific activity & & \multicolumn{3}{c}{ Energy (MeV) } \\
Isotope (T/12-y) & $(\mathbf{M B q} / \mathbf{k g})$ & Decay mode & $\boldsymbol{\alpha}$ & $\boldsymbol{\beta}$ & $\gamma$ \\
${ }^{137} \mathrm{Cs}(30)$ & 3256.0 & $\beta$, IT, $\gamma$ & n/a & $0.19 ; 0.060 .66$ \\
${ }^{241} \mathrm{Am}(430)$ & 129.5 & $\alpha, \gamma$ & 5.5 & 0.052 & 0.033 \\
\hline IT-isomeric transition. & & & &
\end{tabular}

Table 2: Radionuclide properties - power to contaminate relates to impacted area.

\begin{tabular}{cccc} 
Isotope & Chemical form & $\begin{array}{c}\text { Power to } \\
\text { contaminate } \\
\left(\mathbf{T B q} / \mathbf{k m}^{\mathbf{2}}\right)\end{array}$ & $\begin{array}{c}\text { Application and } \\
\text { typical } \backslash \text { activity } \\
\mathbf{T B q}\end{array}$ \\
\hline${ }^{137} \mathrm{Cs}$ & Salt $(\mathrm{CsCl})$ & 1.50 & $\begin{array}{c}\text { Category } 1 \\
\text { Irradiators } \geq 37\end{array}$ \\
& Oxide Powder & 1.50 & Category 2 Well \\
& & & logging $\mathrm{d} \geq 0.37$ \\
\hline
\end{tabular}

\section{RESULTS AND DISCUSSION}

\subsection{Scenario I and II - Figures.}

Table 3 summarizes results of the HotSpot calculations. 
Table 3: Results for the two scenarios using data from ICRP 60 [16].

\begin{tabular}{|c|c|c|c|c|c|c|}
\hline $\begin{array}{l}\text { Scenari } \\
\text { o } \\
\text { Number }\end{array}$ & $\begin{array}{l}\text { Radio- } \\
\text { nuclide }\end{array}$ & $\begin{array}{r}\text { Source Term } \\
\text { (Bq) }\end{array}$ & $\begin{array}{l}\text { Maximum E } \\
\quad(\mathrm{mSv})\end{array}$ & $\begin{array}{c}\text { Maximum E } \\
\text { inner area } \\
\left(\mathbf{k m}^{2)}\right.\end{array}$ & $\begin{array}{c}\text { Maximum } \\
\text { ground } \\
\text { deposition } \\
\left(\mathbf{k B q} / \mathbf{m}^{2)}\right.\end{array}$ & $\begin{array}{c}\text { Maximum } \\
\text { ground } \\
\text { deposition } \\
\text { inner area } \\
\left(\mathbf{k m}^{2)}\right.\end{array}$ \\
\hline I & ${ }^{137} \mathrm{Cs}$ & $48.1 \mathrm{TBq}$ & 419 & 3.2 & $2.2 \times 10^{5}$ & 0.56 \\
\hline II & ${ }^{241} \mathrm{Am}$ & $74.0 \mathrm{GBq}$ & 8900 & 176 & $3.3 \times 10^{2}$ & 0.0005 \\
\hline
\end{tabular}

Figures 2 and 4 show total effective dose contour plots and Figures 3 and 5 show the ground deposition $\left(\mathrm{kBq} / \mathrm{m}^{2}\right)$ along the distance from the explosive spot, for scenarios I and II.

Considering Table 3, on observation of $\mathrm{E}$ for ${ }^{241} \mathrm{Am}$ is 20 times higher than ${ }^{137} \mathrm{Cs}$, while the deposition inner area for ${ }^{137} \mathrm{Cs}$ is 100 times greater than ${ }^{241} \mathrm{Am}$. The maximum ground deposition for ${ }^{137} \mathrm{Cs}$ is 1000 times higher than ${ }^{241} \mathrm{Am}$. This result means that, in this case, all are above the operational intervention levels. At these levels, shown in Table 3, immediate relocation in the explosion place should consider the limits of Table 4. The colored areas in Figures 2 and 4 show the maximum dose distance of $10 \mathrm{~m}$ and the maximum $\mathrm{E}$ of $419 \mathrm{mSv}$ for scenario I and 8,900 $\mathrm{mSv}$ for scenario II. The effective dose inner areas are $3.2 \mathrm{~km}^{2}$ and $176 \mathrm{~km}^{2}$ for scenarios I and II, respectively. Figures 3 and 5 show a $2.2 \times 10^{5} \mathrm{kBq} / \mathrm{m}^{2}$ maximum ground deposition and a $0.56 \mathrm{~km}^{2}$ maximum ground deposition inner area for ${ }^{137} \mathrm{Cs}$, a thousand times greater than that for ${ }^{241} \mathrm{Am}$.

The results show that the radiological hazard by using ${ }^{241} \mathrm{Am}$ is more risky from the viewpoint of total effective dose, and its consequence is more widespread than that of ${ }^{137} \mathrm{Cs}$. 
Figure 2: Google Earth output for plume contour effective dose (Sv), as a function of downwind distance for scenario

I.

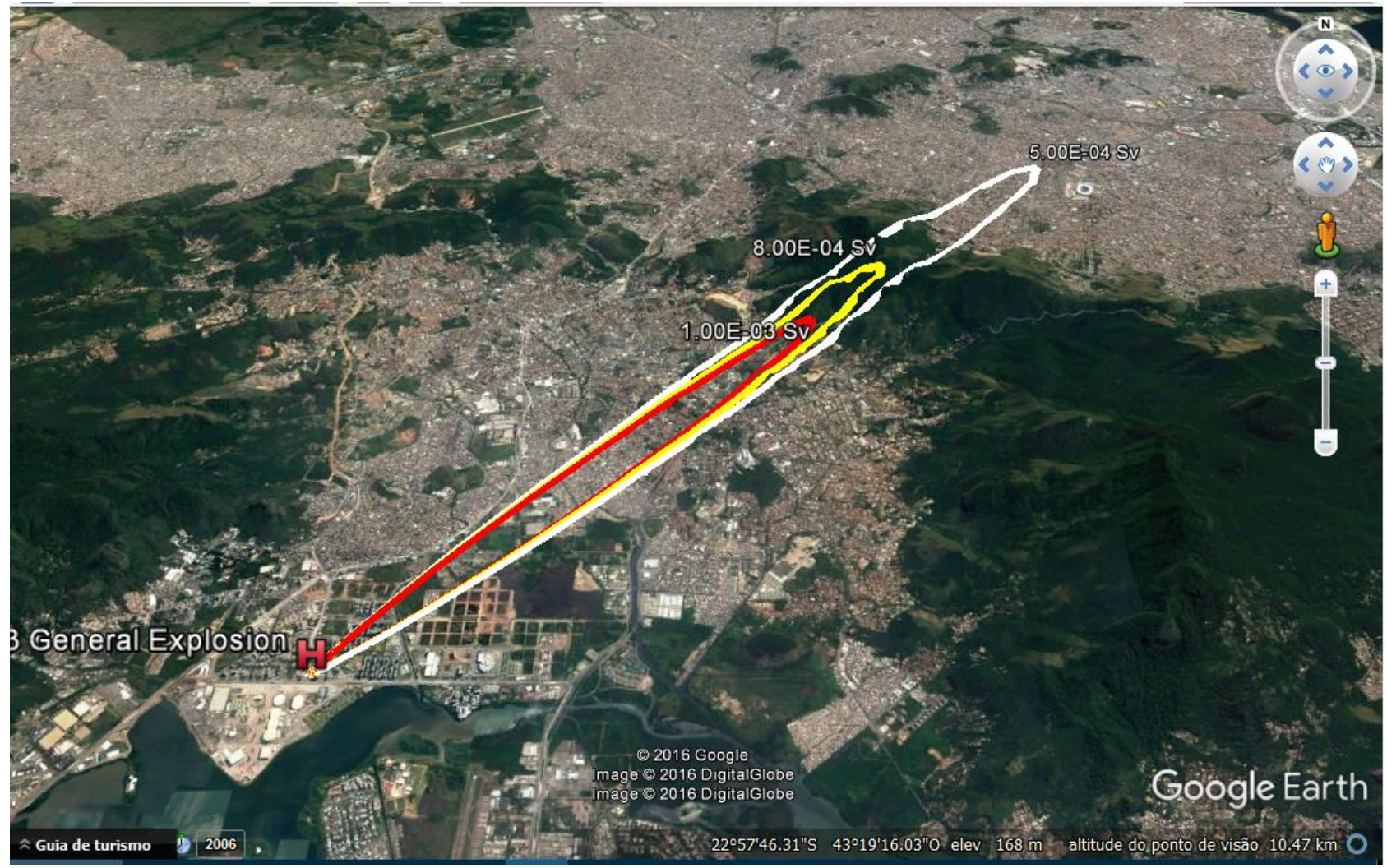


Figure 3: Plume Contour - Ground Deposition $\left(\mathrm{kBq} / \mathrm{m}^{2}\right)$ for scenario I.

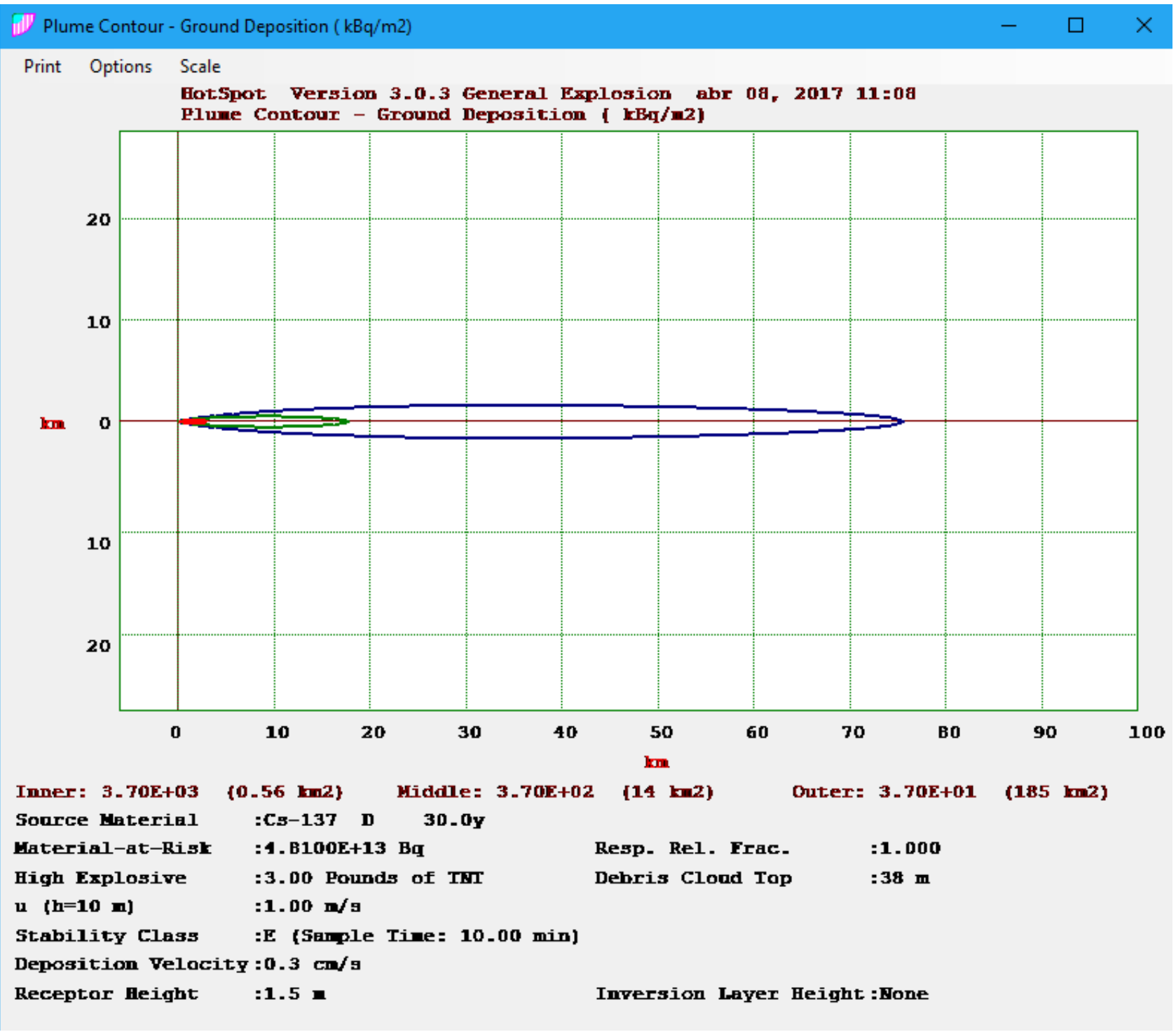


Figure 4: Google Earth output for plume centerline effective dose (Sv), as a function of downwind distance.

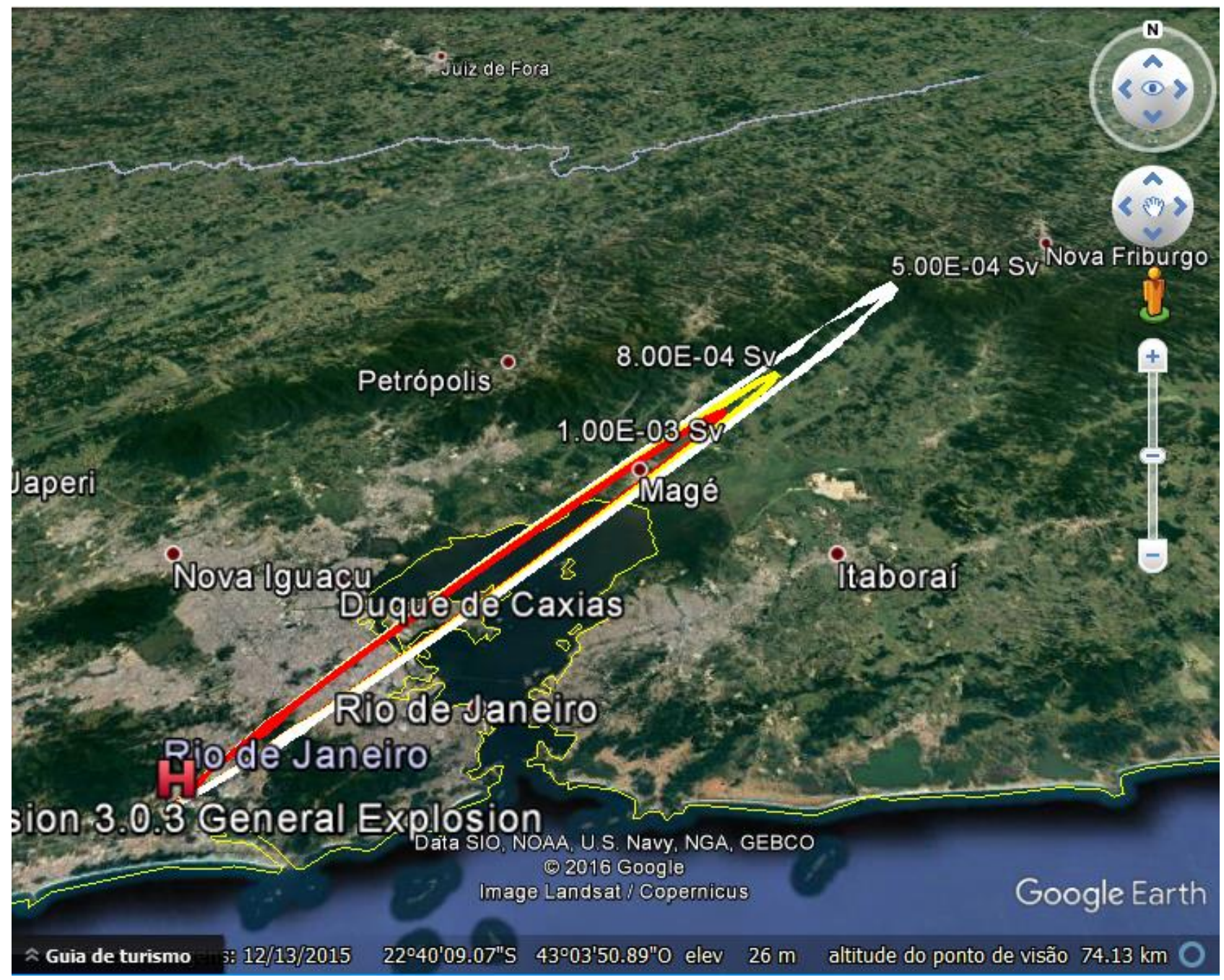


Figure 5: Plume Contour - Ground Deposition $\left(\mathrm{kBq} / \mathrm{m}^{2}\right)^{-}$, as a function of distance for scenario

\section{II.}

\section{(ill Plume Contour - Ground Deposition ( $\mathrm{kBq} / \mathrm{m} 2)$}

$\square \times$

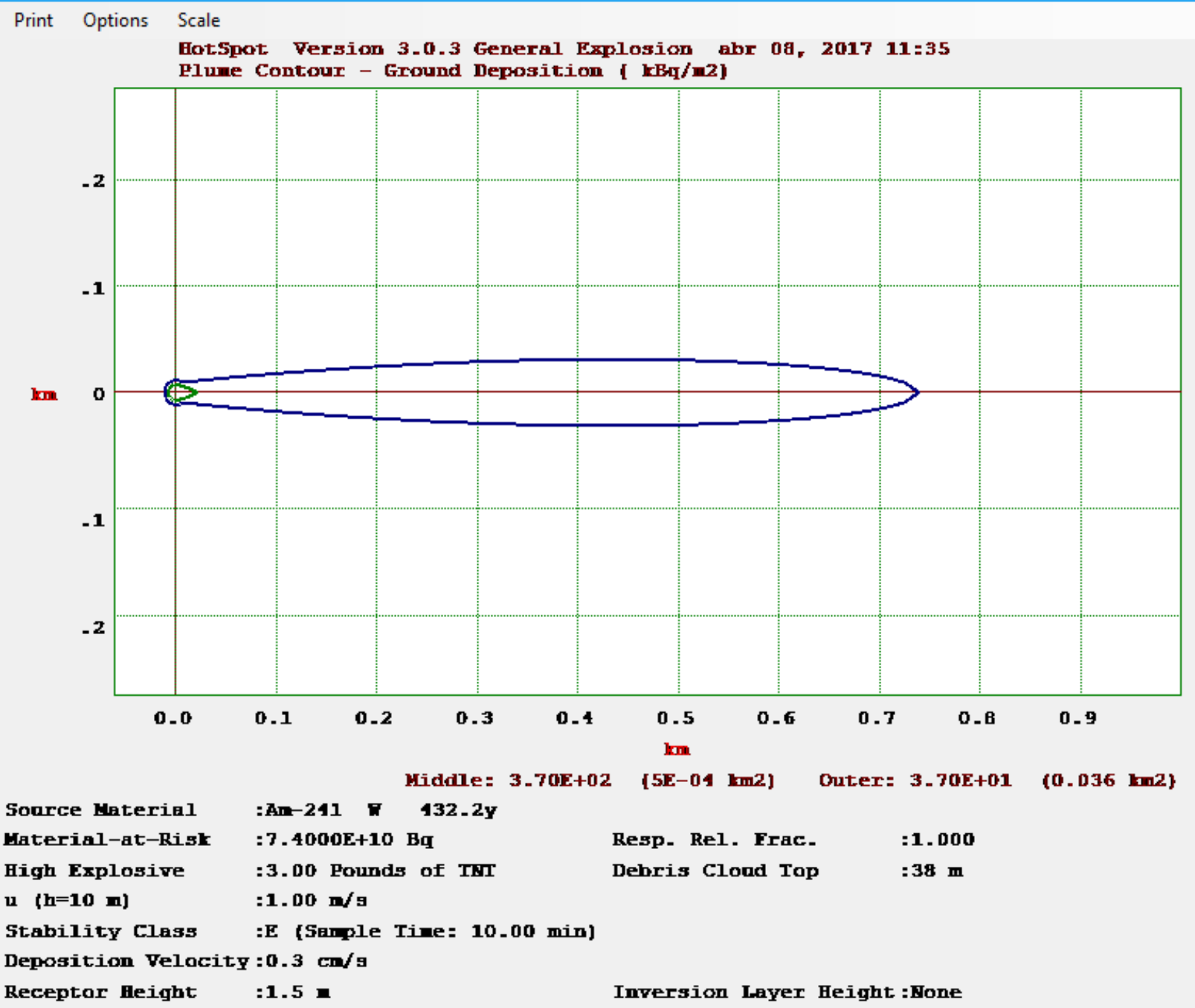




\subsection{Protective actions and first responders}

Table 4 shows the effective dose per recommended protective action [20].

Table 4: Effective dose per recommended protective action.

\begin{tabular}{ll}
\hline Protective action & Operation intervention level \\
\hline Indoor sheltering & $10 \mathrm{mSv}$ for 2 weeks \\
Temporary evacuation & $50 \mathrm{mSv}$ for 1 week \\
Iodine tablet & $100 \mathrm{mSv}$ for thyroid \\
Relocation & $100-1000 \mathrm{mSv}$ for 1 year \\
\hline
\end{tabular}

Considering both cases simulated to induce a conclusion, the internal exposure by inhalation of ${ }^{241} \mathrm{Am}$ could require more serious countermeasures than those for the external exposure by ${ }^{137} \mathrm{Cs}$. The initial point for determining the extent of the "hot zone" in the Olympic Village, for potential ground shine exposure, is the initial screening to quickly delineate effective dose "boundary lines". It is of great importance for adequate respiratory protection to reduce the amount of radioactive material inhaled by the first responders. The US NARAC HotSpot code outputs are a useful tool to give a quick answer regarding radiological contamination in the "hot zone". It is very important to optimize the rescue operations of first responders and to allow safe escape routes for the athletes. The mitigation of the consequences of the hazardous material released requires good training to prepare the emergency first responders effectively [21].

The US NARAC HotSpot code is also helpful for preventative actions and implementing countermeasures of emergency preparedness and response systems. It would provide quantitative model outputs that may guide the deployment of health physics survey teams and assist in making more specific emergency management decisions, in the case of ${ }^{241} \mathrm{Am}$ releases. Responders should be trained through a combination of tabletop, field exercises, and classroom instruction. The first responders must have detectors and personal protective equipment. 


\section{CONCLUSION}

A procedure calculation combined two realistic potential scenarios in the case of a terrorist attack, involving the explosion of a dirty bomb in the Olympic Village during the Rio 2016 Olympic Games. Two representative radionuclides were considered, ${ }^{137} \mathrm{Cs}$ and ${ }^{241} \mathrm{Am}$, using the US NARAC HotSpot code and data obtained from ICRP 60, showing the maximum effective dose distance of 10 $\mathrm{m}$ from the explosion spot, and the maximum $\mathrm{E}$ of $8,900 \mathrm{mSv}$ for ${ }^{241} \mathrm{Am}$. Inversely, it was observed that ${ }^{137} \mathrm{Cs}$, as a salt, had a ground deposition for an area greater than that of ${ }^{241} \mathrm{Am}$. These results will assist the radiological first responders, as a precious working tool, in how to prepare, make decisions, inform the public, and act together with other institutions such as the civil defense, policemen, fire brigade, health physics team, and local authorities. Although these results are related to ${ }^{137} \mathrm{Cs}$ and ${ }^{241} \mathrm{Am}$, other radionuclide in further research could be suggested for simulations of dirty bomb explosions at any big event.

\section{REFERENCES}

[1] NAUS (2004). The National Academies and the U.S. Department of Homeland Security, Washing-ton, DC, USA, Radiological attack dirty bombs and other devices. Available at: https://www.dhs.gov/xlibrary/assets/prep_radiological_fact_sheet.pdf.

[2] SHIN (2009). Hyeongki Shin and Juyoul Kim, 2009. Development of realistic RDD scenarios and their radiological consequence analyses. Applied Radiation and Isotopes, 67 (2009)1516-1520.

[3] IAEA (2005). International Atomic Energy Agency. Protecting people against radiation exposure in the event of a radiological attack. ICRP Publication 96. Vienna: IAEA, 2005. 41 p.

[4] IAEA (2003a). International Atomic Energy Agency. Categorization of Radioactive sources, IAEA-TECDOC-1344, Vienna: IAEA, 2003. 33p.

[5] MUSOlinO, S.V., HARPER, F.T., BUDDEMEIER, B., BROWN, M., SCHLUECK, R. (2013). Updated Emergency Response Guidance for the First $48 \mathrm{~h}$ after the Outdoor Detonation of an Ex-plosive Radiological Dispersal Device. Health Phys;105(1);65-73.

[6] IAEA (2009). Nuclear Security Measures at the XV Pan American Games: Rio de Janeiro 2007. Tech. Rep.,Vienna, Austria. 
[7] IAEA (2012). International Atomic Energy Agency. Nuclear Security Systems and Measures for Major Public Events. IAEA Nuclear Security Series No. 18, Vienna: IAEA, 2012.

[8] HOMANN, S. G., (2011). HotSpot Ver3.01, Health Physics Codes for PC, LLNL, Livermore, CA, USA. 56 p.

[9] ROTHER, F. C., REBELLO, W. F., HEALY, M.J.F., SILVA, M. M., CABRAL, P.M., VITAL, H. C.and ANDRADE, E. R. (2016). Radiological Risk Assessment by Convergence Methodology Model in RDD Scenarios. Risk Analysis, Vol. 36, No. 11.

[10] EPA (1978). Environmental Protection Agency (1978), Guideline on Air Quality Models, OAQPS Guideline Series No. 1.2-080, Report EPA-45012-78-027 (Office of Air Quality Planning and Standards, Research Triangle Park, NC).

[11] SUTTON, O. G. (1932), "A Theory of Eddy Diffusion in the Atmosphere," Proceedings of the Royal Society, Series A, 135, p. 143 (London).

[12] PASQUILL, F. (1961), "The Estimation of Dispersion of Windborne Material," Meteorology, 90, pp. 3349.

[13] PASQUILL, F. (1974). Atmospheric Diffusion, 2nd. ed. (John Wiley \& Sons, New York).

[14] GIFFORD, F. A., Jr. (1975), "Atmospheric Dispersion Models for Environmental Pollution Appli-cations," Lectures on Air Pollution and Environment Impact Analyses, pp. 3558 (American Mete-orological Society, Boston, MA).

[15] BRIGGS, G. A. (1975). "Plume Rise Predictions", Lectures on air Pollution and Environmental Impact Analyses, Workshop Proceedings, pp 59-111 (American Meteorology Society, Boston, MA.

[16] ICRP (1990). International Commission on Radiological Protection, Recommendations of the International Commission on Radiological Protection; ICRP 60; ICRP Vol. 21/1-3; ISBN-13: 9780-08-041144-6; Elsevier Publication.

[17] FERGUSON, C.D., KAZI, T. and PERERA, J. (2003). Commercial radioactive sources, Occasional paper no. 11, Center for Nonproliferation Studies, Monterey Institute of International Studies, California 93940, USA, ISBN 1-885350-06-6.

[18] CONNELL, Len. ICSSRS (2013). International Conference on the Safety and Security of Radioactive Sources. Overview of the US NAS Report: Radiation Source Use and Replacement, Abu Dhabi, UAE, 27-31.

[19] ICRU (1998). International Commission on Radiation Units and Measurements. Fundamental quantities and units for ionizing radiation. ICRU Report 60, Bethesda: ICRU, 1998. 
[20] ICRP (2005). International Commission on Radiological Protection, Publication 96: Protecting people against radiation exposure in the event of a radiological attack, Annals of the ICRP 35 (1), $1-110$.

[21] IAEA (2003b). International Atomic Energy Agency. Method for developing arrangements for response to a nuclear or radiological emergency, IAEA-TECDOC No. 953, Vienna: IAEA, 265 p. 